\title{
KINETIKA REAKSI HIDROKSILASI EPOKSI MINYAK JARAK PAGAR MENGGUNAKAN KATALIS BENTONIT
}

\author{
Ratri Ariatmi Nugrahani*, Flora Elvistia Firdaus, Yeti Widyawati, \\ Hana Firginia, Riris Purnama \\ Jurusan Teknik Kimia, Fakultas Teknologi Industri, Universitas Jayabaya \\ Jalan Raya Bogor Km. 28,8 Cimanggis, Jakarta Timur 16954 \\ Email: r_nugrahani@yahoo.com
}

\begin{abstract}
Abstrak
Berdasarkan sifat-sifat komposisi asam lemak dan bilangan iodium, minyak jarak pagar (Jatropha curcas) berpotensi menjadi bahan dasar pelumas. Meskipun demikian, kandungan ikatan tidak jenuh minyak ini menurunkan kestabilan oksidasinya. Kestabilan oksidasi ini dapat diperbaiki melalui modifikasi kimiawi dengan reaksi epoksidasi yang menghilangkan ikatan rangkap. Ini dilakukan melalui reaksi hidroksilasi dengan membuka ikatan gugus oksirana epoksi. Tujuan penelitian ini adalah mengkarakterisasi produk, serta mempelajari kinetika reaksi pembukaan cincin oksirana oleh metanol dengan katalis bentonit untuk membentuk poliol. Hasil analisis FTIR produk reaksi menunjukkan penurunan intensitas gugus epoksi pada bilangan gelombang $824-842 \mathrm{~cm}^{-1}$ dan munculnya gugus hidroksil pada bilangan gelombang 3450-3800 $\mathrm{cm}^{-1}$. Bilangan oksirana epoksi jarak pagar berkurang dari 4,7\% menjadi $0,05 \%$ setelah pembukaan cincin. Bilangan hidroksil poliol adalah sebesar 165,77 . Pengukuran kinetika pembukaan cincin pada gugus oksirana dari epoksi jarak pagar dilakukan pada 50,60 , dan $65^{\circ} \mathrm{C}$. Analisis data laju reaksi yang dianalisis dengan pendekatan sistem pseudohomogen menunjukkan bahwa reaksi mengikut kinetika orde-1 semu. Dari perubahan laju reaksi terhadap temperatur diperoleh nilai entalpi reaksi dan energi aktivasi sebesar masing-masing 8,27 kkal mol-1 dan 7,63 kkal mol-1.
\end{abstract}

Kata kunci: epoksi jarak pagar, hidroksil, oksirana, bentonit, kinetika

\begin{abstract}
HYDROXYLATION KINETICS OF JATROPHA OIL EPOXY USING BENTONITE CATALYST. Based on chemical properties such as fatty acid compositions and iodium value, Jatropha curcas oil can potentially be applied as lubricant. Unsaturation of this oil decreases its oxidative stability. Improvement of this property may be done by chemical modification involving epoxidation and oxirane ring opening with bentonite catalyst, forming polyol by hydroxylation. The purpose of this research is to characterize the products and kinetics of the oxirane ring opening reaction. The results of chemical analysis by titration for residual oxiranes and hydroxyl formed in the reaction system, was showed using IR spectroscopy. Their effects were to reduce epoxy groups at $824-842 \mathrm{~cm}^{-1}$ and appearance of hydroxyl groups at the $\mathrm{OH}$ characteristic absorption peak from $3450-3800 \mathrm{~cm}^{-1}$. The oxirane number of epoxidized jatropha oil was reduced from $4.7 \%$ to $0.05 \%$ by ring opening. The kinetics of the oxirane ring opening of epoxidized Jatropha curcas oil by methanol with bentonite was studied at 50,60 , and $65^{\circ} \mathrm{C}$. The oxirane ring opening analyzed by the pseudo-homogeneous approach followed a pseudo-first order kinetics. From the temperature dependence of the rate, reaction enthalpy $(\Delta H)$ and activation energy $\left(\Delta E_{\mathrm{a}}\right)$ were found to be $8,27 \mathrm{kcal} \mathrm{mol}^{-1}$ and 7,63 $\mathrm{kcal} \mathrm{mol}^{-1}$, respectively.
\end{abstract}

Keywords: epoxidized jatropha curcas, hydroxyl, oxirane, bentonite, kinetic

*penulis korespondensi 


\section{PENDAHULUAN}

Minyak jarak pagar (Jatropha curcas) mengandung asam oleat sebesar 40,10\%, asam linoleat $37,51 \%$, dengan bilangan iodiumi antara 98,89-105,2 (Nzikou dkk., 2009). Hasil penelitian Nugrahani (2008) menyatakan bahwa kandungan asam oleat minyak jarak pagar adalah sebesar 47,97\% dengan bilangan iodiumi 90-108,5. Menurut Talkit dkk. (2012), bilangan iodium menunjukkan tingkat ketidakjenuhan minyak nabati, sebagai salah satu alternatif parameter untuk pengujian oksidasi dan dapat menunjukkan kualitas drying suatu jenis minyak. Minyak nabati dengan bilangan iodium 94-126 dapat digunakan sebagai base oil pelumas. Minyak nabati jenis drying oil memiliki bilangan iodium tinggi. Pada penggunaan sebagai pelumas, sebaiknya minyak nabati memiliki bilangan iodium rendah (Kaurav, 2011). Menurut Chauhan (2008), minyak nabati dengan bilangan iodium di bawah 100 termasuk ke dalam non drying oil dan di antara 100-130 termasuk ke dalam semi drying oil. Dengan demikian, minyak jarak pagar mempunyai potensi untuk digunakan sebagai base oil pelumas. Meskipun demikian, kandungan ikatan $\mathrm{C}$ rangkap dalam minyak mengakibatkannya mudah teroksidasi sehingga menurunkan kestabilan oksidasi. Beberapa modifikasi kimiawi pada trigliserida dapat dilakukan untuk meningkatkan stabilitas, misalnya proses epoksidasi dan hidroksilasi membentuk poliol.

Epoksidasi adalah reaksi pembentukan gugus oksirana atau epoksida, yaitu reaksi antara ikatan rangkap olefin maupun aromatic dengan asam peroksida (Okieimen dkk., 2002). Hidroksilasi adalah proses mensubstitusi gugus hidroksil $(-\mathrm{OH})$ dalam suatu senyawa organik. Sebelum proses hidroksilasi, cincin pada gugus oksirana harus dibuka terlebih dahulu (Purwanto, 2010). Hasil penelitian Hwang dan Erhan pada tahun 2006, menyatakan bahwa pembukaan cincin pada gugus oksirana epoksi minyak kedelai menggunakan alkohol Guerbet dan asam sulfat $0,5 \mathrm{ml} / 100 \mathrm{~g}$ epoksi kedelai. Hal ini dideterminasi dengan pengamatan hilangnya sinyal gugus fungsi epoksi menggunakan metode Fourier Transform Infra Red (FTIR), yaitu $822 \mathrm{~cm}^{-1}$. Reaksi pembukaan cincin pada gugus oksirana dengan 3 jenis alkohol yang berbeda, yaitu n-butanol, iso-amil alkohol dan 2-etilheksanol, diamati dengan cara titrasi terhadap gugus oksirana. Reaksi yang terjadi dikonfirmasi dengan menggunakan spektroskopi infra merah, yaitu kehilangan gugus oksirana pada bilangan gelombang $822 \mathrm{~cm}^{-1}$ dan tampaknya puncak hidroksil pada $3450 \mathrm{~cm}^{-1}$ (Lathi dan Mattiasson, 2006). Liu dkk. (2008) melakukan penelitian mengenai penggunaan resin Amberlyst-15 pada reaksi pembukaan cincin gugus oksirana dengan menggunakan beberapa jenis alkohol, dengan perolehan 4095\%. Hasil penelitian Purwanto (2010) menunjukkan bahwa kondisi hidroksilasi optimal terjadi selama 126 menit, pada suhu $49{ }^{\circ} \mathrm{C}$, dan menghasilkan poliol dengan bilangan hidroksil sebesar 161,5 mg KOH/ g minyak. Poliol kedelai yang disintesis dari epoksi minyak kedelai dan metanol, memberikan hasil dengan bilangan hidroksil sebesar 213 mg KOH/g (Petrovic dkk., 2003).

Tahapan reaksi katalitik heterogen, menurut Hodar (2009) adalah sebagai berikut: (1) Difusi reaktan ke dalam katalis; (2) Adsorpsi reaktan ke permukaan; (3) Perubahan kimiawi di permukaan, pembentukan senyawa kompleks teradsorb; (4) Dekomposisi senyawa kompleks teradsorb (produk di permukaan); (5) Desorpsi dan difusi produk reaksi dari katalis. Beberapa model kinetika yang digunakan pada reaksi katalitik padat antara lain mengikuti mekanisme Langmuir-Hinshelwood dan EleyRidel. Beberapa hasil penelitian oleh Zeng dkk. (2012) menunjukkan bahwa katalis Alpillarized clay (Al-PILC) mempunyai aktivitas tinggi untuk reaksi esterifikasi n-pentanol dengan asam benzoat. Kinetika reaksi esterifikasi dapat ditentukan berdasar-kan teori pseudo-homogen, yaitu dengan asumsi tidak adanya difusi intrapartikel. Kecepatan pengadukan yang cukup tinggi mampu mengatasi tahanan difusi. Megawati dkk. (2010) menuliskan bahwa umumnya reaksi padat-cair dimodelkan dengan meng-gunakan pendekatan heterogen atau pseudo-homogen. Menurut Rustamaji dkk. (2010), reaksi transesterifikasi dengan katalis padat dapat didekati dengan model reaksi pseudohomogen, karena tahanan perpindahan massa eksternal dan difusi internal katalis dapat diabaikan.

Nugrahani (2008) menyatakan bahwa pemilihan katalis padat untuk reaksi hidroksilasi terhadap epoksi minyak jarak pagar ditinjau berdasarkan rasio $\mathrm{Si} / \mathrm{Al}$ dan keasaman minimum katalis. Faktor lain yang berpengaruh pada reaksi katalitik padat 
adalah kemampuan adsorpsi katalis. Kemampuan adsorpsi bentonit terhadap ester forbol dalam minyak jarak pagar sangat baik (El-Diwani dkk., 2012). Kemampuan menyerap metanol pada permukaan bentonit cukup kuat (Bargaya, 1981). Kemampuan bentonit yang baik dalam difusi dan adsorpsi ini, digunakan sebagai dasar pendekatan model pseudo-homogen.

Penelitian mengenai kinetika pembukaan cincin pada gugus oksirana pada reaksi epoksi minyak kedelai dengan metana tanpa katalis dipelajari oleh Lin (2008). Epoksidasi terjadi pada 50,60, 65, dan $70{ }^{\circ} \mathrm{C}$, dengan persamaan laju reaksi k.Ep.Me ${ }^{2}$. Parameter termodinamika, seperti entalpi $(\Delta \mathrm{H})$, entropi $(\Delta \mathrm{S})$, dan energy aktivasi (Ea) adalah 76,08 $\mathrm{kJ} \mathrm{mol}^{-1},-118,42 \mathrm{~J} \mathrm{~mol}^{-1} \mathrm{~K}^{-1}$, dan $78,56 \mathrm{~kJ} \mathrm{~mol}^{-1}$.

Tujuan penelitian ini adalah membandingkan beberapa pereaksi dan katalis pada reaksi hidroksilasi terhadap epoksi jarak pagar. Perbandingan ini mencakup karakterisasi dan identifikasi produk poliol yang terbentuk, serta kinetika reaksi pembukaan cincin pada gugus oksirana.

\section{METODE}

Bahan baku yang digunakan dalam penelitian ini adalah minyak jarak pagar dengan berat jenis $0,9393 \mathrm{~g} / \mathrm{mL}$ dan bilangan iodium $108 \mathrm{~g} / 100 \mathrm{~g}$, Asam asetat glasial 99\%, Hidrogen peroksida 50\%, Asam sulfat 98\%, metanol, dan bentonit.

\section{Reaksi Epoksidasi}

Minyak jarak pagar sebanyak $100 \mathrm{~mL}$ dicampurkan dengan asam asetat glasial sebanyak 17,6 mL dan katalis $\mathrm{H}_{2} \mathrm{SO}_{4} 98 \%$ ditambahkan sebanyak 1\% dari volume total (Nugrahani dkk., 2008). Campuran minyak jarak pagar, asam asetat glasial, katalis $\mathrm{H}_{2} \mathrm{SO}_{4}$ 98\% diaduk dan dipanaskan dalam thermostat bath sampai dengan $60{ }^{\circ} \mathrm{C}$, selanjutnya hidrogen peroksida 50\% sebanyak $34,1 \mathrm{~mL}$ ditambahkan demi tetes sampai habis selama 1 jam. Produk didinginkan dan didekantasi. Epoksi yang terbentuk dicuci dengan menggunakan air. Analisis dilakukan untuk menentukan bilangan oksirana.

\section{Reaksi Hidroksilasi}

Epoksi jarak pagar dihidroksilasi menggunakan metanol dengan rasio mol epoksi:metanol sebesar 1:13. Bentonit sebanyak 1,5 persen berat total (epoksi dan metanol) digunakan sebagai katalis, (Nugrahani dkk., 2007). Reaksi dilakukan pada suhu $50{ }^{\circ} \mathrm{C}$ dan analisis secara kuantitatif dilakukan menggunakan parameter bilangan oksirana dan bilangan hidroksil. Sebagai pembanding adalah reaksi hidroksilasi terhadap epoksi jarak pagar menggunakan asam asetat dengan perbandingan mol epoksi: asam asetat sebesar 1:7,1 dan katalis ion resin $15 \%$ dari berat total (epoksi dan asam asetat), yang dilakukan pada suhu $80{ }^{\circ} \mathrm{C}$, dan waktu 50 menit (Nugrahani dkk., 2012). Pembanding lain adalah reaksi hidroksilasi terhadap epoksi minyak jarak pagar menggunakan pereaksi etilen glikol dengan perbandingan volume epoksi:etilen glikol sebesar 1:1 dan katalis asam sulfat sebanyak 1\% dari volume total (epoksi dan etilen glikol), pada suhu 120 ${ }^{\circ} \mathrm{C}$, dan waktu 90 menit.

Kajian kinetika dilakukan pada penggunaan katalis dengan reaksi yang lebih baik, ditandai dengan besarnya penurunan nilai oksirana. Pengamatan dilakukan dengan cara mengambil sampel setiap waktu tertentu dan dianalisis bilangan oksirana setelah bereaksi. Hasil reaksi dikonfirmasi secara kualitatif dengan menggunakan Fourier Transform Infrared Spectroscopy (FTIR). Identifikasi kimiawi dilakukan dengan cara titrasi sisa oksirana dan gugus hidroksil yang terbentuk.

\section{HASIL DAN PEMBAHASAN Hidroksilasi terhadap Epoksi Jarak Pagar} Reaksi Hidroksilasi terhadap epoksi jarak pagar membentuk poliol, diukur dengan mencatat perubahan bilangan oksirana sebelum dan sesudah reaksi. Pada penelitian ini dibandingkan 3 jenis pereaksi, yaitu metanol, asam asetat, etilen glikol dan 3 jenis katalis, yaitu bentonit, resin penukar ion, dan asam sulfat, yang direaksikan dengan epoksi minyak jarak pagar. Tabel 1 menunjukkan data penurunan bilangan oksirana setelah terjadinya reaksi hidroksilasi.

Dari Tabel 1, pada suhu $50{ }^{\circ} \mathrm{C}$, waktu reaksi 180 menit, metanol berlebih, dengan menggunakan katalis padat bentonit, bilangan oksirana berkurang relatif banyak dan membentuk gugus hidroksil. Sebagai perbandingan ditampilkan hasil reaksi menggunakan katalis resin penukar ion dan pereaksi asam asetat, serta dengan katalis asam sulfat dan pereaksi etilen glikol. Pada suhu reaksi lebih tinggi, gugus hidroksil yang dihasilkan lebih sedikit. Dengan menggunakan 
Tabel 1. Penurunan Bilangan Oksirana Setelah Reaksi Hidroksilasi pada Epoksi Minyak Jarak Pagar

\begin{tabular}{|c|c|c|c|c|c|c|c|}
\hline \multirow[b]{2}{*}{ Pereaksi } & \multicolumn{4}{|c|}{ Kondisi Operasi } & \multirow{2}{*}{$\begin{array}{c}\text { Bilangan } \\
\text { Oksirana } \\
(\%) \\
\text { sebelum } \\
\text { reaksi } \\
\end{array}$} & \multirow{2}{*}{$\begin{array}{c}\text { Bilangan } \\
\text { Oksirana } \\
(\%) \\
\text { setelah } \\
\text { reaksi }\end{array}$} & \multirow[b]{2}{*}{$\begin{array}{l}\text { Bilangan } \\
\text { Hidroksil }\end{array}$} \\
\hline & $\begin{array}{c}\text { Suhu } \\
\left({ }^{\circ} \mathrm{C}\right)\end{array}$ & $\begin{array}{c}\text { Waktu } \\
\text { (menit) }\end{array}$ & Katalis & $\begin{array}{c}\text { Rasio mol } \\
\text { Epoksi: } \\
\text { Pereaksi } \\
\end{array}$ & & & \\
\hline Metanol & 50 & 180 & $\begin{array}{l}\text { Bentonit } \\
1,5 \% \\
\text { (total } \\
\text { berat) }\end{array}$ & $1: 13$ & 4,70 & 0,050 & 165,77 \\
\hline $\begin{array}{l}\text { Asam } \\
\text { Asetat }\end{array}$ & 80 & 50 & $\begin{array}{l}\text { Ion resin } \\
15 \% \\
\text { (total } \\
\text { berat) }\end{array}$ & $1: 7,1$ & 1,43 & 0,220 & 63,70 \\
\hline $\begin{array}{l}\text { Etilen } \\
\text { Glikol }\end{array}$ & 120 & 90 & $\begin{array}{l}\text { Asam } \\
\text { sulfat 1\% } \\
\text { (total } \\
\text { volume) }\end{array}$ & $1: 1$ & 1,87 & 0,021 & 120,69 \\
\hline
\end{tabular}

katalis cair, pemisahan katalis dari produk menjadi lebih sulit dibandingkan dengan menggunakan katalis padat. Kajian kinetika reaksi hidroksilasi terhadap epoksi jarak pagar pada penelitian ini menggunakan pereaksi metanol dengan perbandingan mol 1:13 dan katalis bentonit 1,5\%-b, pada suhu $50{ }^{\circ} \mathrm{C}$ dan sampel diambil setiap rentang waktu tertentu.

\section{Identifikasi Hasil Reaksi Hidroksilasi}

Pembukaan ikatan pada gugus oksirana oleh metanol dengan menggunakan katalis bentonit diamati dengan melakukan titrasi terhadap oksirana. Bilangan oksirana minyak jarak pagar adalah sebesar $4,7 \%$ dan hasil pembukaan ikatan pada gugus oksirana menghasilkan bilangan oksirana sebesar 0,05\%. Konversi reaksi pembukaan ikatan pada gugus oksirana adalah sebesar 98,9\% $((4,7 \%-0,05 \%) / 4,7 \%))$. Terjadinya reaksi dikonfirmasi secara kuantitatif dengan menggunakan spektrum Infra Merah, untuk menunjukkan adanya gugus hidroksil. Respon yang terlihat pada reaksi hidroksilasi epoksi, adalah berkurangnya gugus oksirana dengan panjang gelombang $824-842 \mathrm{~cm}^{-1}$ dan tampak adanya gugus hidroksil, yaitu gugus $\mathrm{OH}$ pada puncak penyerapan $3450-3800 \mathrm{~cm}^{-1}$, dengan nilai bilangan hidroksil hasil reaksi hidroksilasi adalah sebesar 165,77. Gambar 1 adalah spektrum IR Poliol jarak pagar.

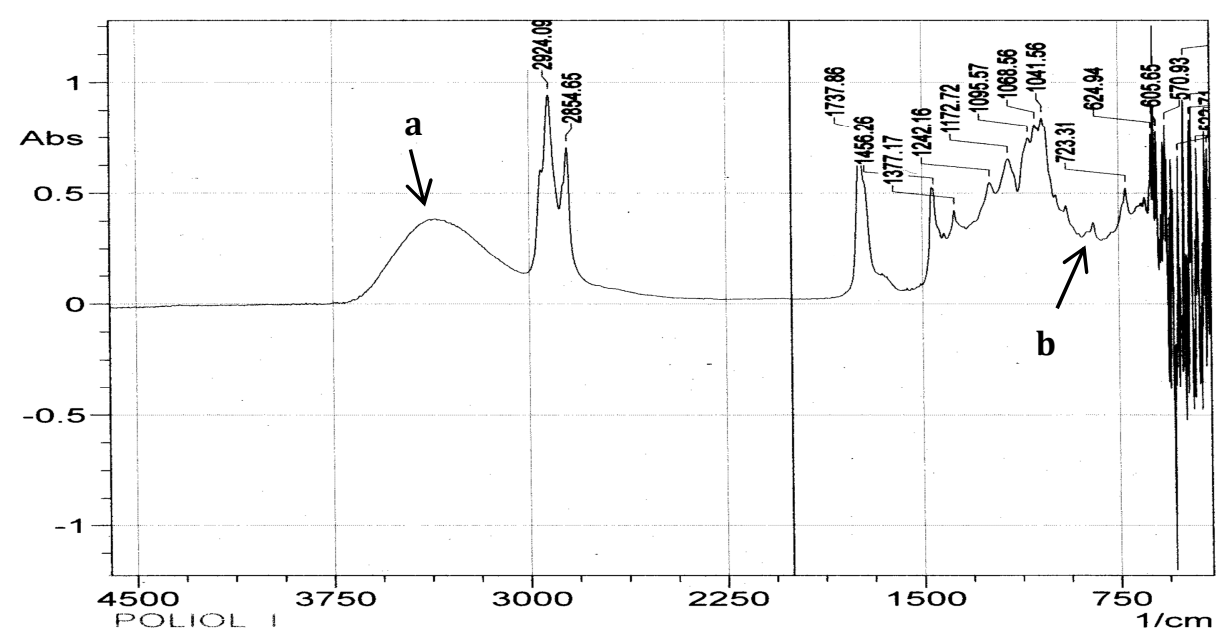

Gambar 1. Spektrum infra merah poliol minyak jarak pagar (a) Gugus hidroksil pada panjang gelombang $3450-3800 \mathrm{~cm}^{-1}$ (b) Gugus oksirana pada panjang gelombang 824-842 cm-1 $^{-1}$ 


\section{Kinetika Reaksi Hidroksilasi pada Epoksi Jarak Pagar}

Reaksi kimia yang terjadi pada proses hidroksilasi dapat membuka cincin gugus oksirana sehingga terbentuk gugus $\mathrm{OH}$ dari Poliol, yaitu mengikuti reaksi seperti pada Gambar 2. Pembukaan cincin epoksida menggunakan alkohol primer, sekunder, dan tersier dengan katalis heterogen, akan membentuk $\beta$-alkoxy alcohols dengan yield sebesar 40-95\% (Liu dkk., 2008). Mengacu pada mekanisme reaksi pembukaan gugus oksirana yang dituliskan oleh Campanella, (2006) dan Kiatsimkul dkk. (2008), yaitu terbukanya gugus oksirana yang diikuti dengan masuknya R'-OH, maka reaksi hidroksilasi terhadap epoksi jarak pagar adalah seperti pada Gambar 2.

Laju reaksi hidroksilasi sebanding dengan kecepatan berkurangnya konsentrasi oksirana dalam epoksi minyak jarak pagar. Penentuan laju reaksi menggunakan pendekatan sebagai reaksi elementer, yaitu berhubungan dengan stoikiometri reaksi. Pendekatan lain adalah merupakan sistem pseudo-homogen berdasarkan Olebunne dkk. (2011), penggunaan alkohol berlebih pada reaksi esterifikasi dengan katalis lempung, mengakibatkan katalis melepaskan sebagian asam ke dalam larutan, sehingga diasumsikan bahwa laju berkurangnya konsentrasi oksirana hanya ditentukan oleh reaksi kimia dengan mengabaikan transfer massa. Dengan demikian, persamaan laju reaksi adalah sebagai berikut:

$-r_{E}=-d C_{E} / d t=k C_{E} . C_{M}$

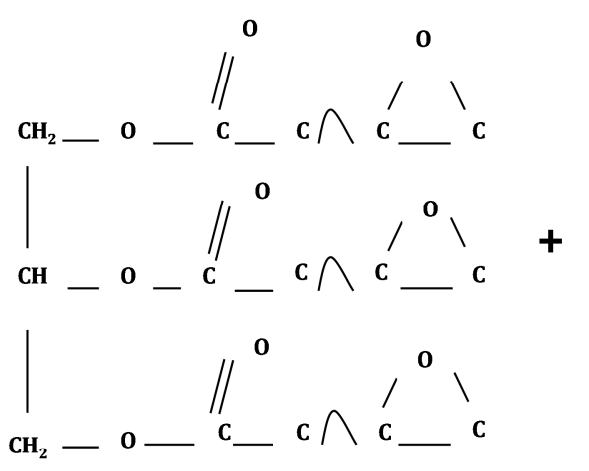

Epoksi Jarak Pagar
Ratio mol $\mathrm{C}_{\mathrm{M}} / \mathrm{C}_{\mathrm{E}}$ adalah $13 / 1$, sehingga diasumsikan $\mathrm{C}_{\mathrm{M}}$ konstan dan $\mathrm{k} \times \mathrm{C}_{\mathrm{M}}$ menjadi konstanta $\mathrm{k}^{\prime}$. Maka Persamaan 1 dapat diselesaikan menurut kinetika orde-1, menjadi:

$\frac{-d C_{E}}{d t}=k^{\prime} \cdot C_{E}$

$\left(\ln \frac{C_{E 0}}{C_{E}}\right)=k t$

Selanjutnya, dengan menggunakan Persamaan 3 , kurva hubungan $t$ dengan $\ln \left(\mathrm{C}_{\mathrm{E} 0} / \mathrm{C}_{\mathrm{E}}\right)$ dari data percobaan perubahan konsentrasi epoksi $\left(\mathrm{C}_{\mathrm{E}}\right)$ dengan perubahan waktu ( $\left.\mathrm{t}\right)$ dapat dibangun. Jika berupa garis lurus, maka asumsi laju reaksi penurunan konsentrasi epoksi orde 1 (satu) semu terhadap konsentrasi epoksi minyak jarak pagar $\left(\mathrm{C}_{\mathrm{E}}\right)$ adalah benar dan nilai konstanta laju reaksi (k) adalah kemiringan kurva tersebut. Gambar 3,4,5 merupakan reaksi hidroksilasi pada suhu $50{ }^{\circ} \mathrm{C}, 60^{\circ} \mathrm{C}$, dan $65^{\circ} \mathrm{C}$.

Kurva pada Gambar 3, 4, dan 5 menunjukkan kecenderungan membentuk garis lurus dan ditunjukkan dengan besarnya $\mathrm{R}^{2}$ masing-masing yaitu 0,9266, 0,928, dan 0,9529 , yang berarti $R^{2}$ semakin besar dan mendekati 1, maka semakin besar kesesuaian antara model persamaan dengan hasil percobaan. Asumsi laju reaksi hidroksilasi terhadap epoksi jarak pagar oleh metanol merupakan reaksi orde 1 semu (Persamaan 2) terhadap konsentrasi epoksi adalah benar. Besarnya nilai konstanta laju reaksi semu (k') merupakan kemiringan persamaan regresi linear ketiga kurva di atas, seperti terdapat pada Tabel 1 .

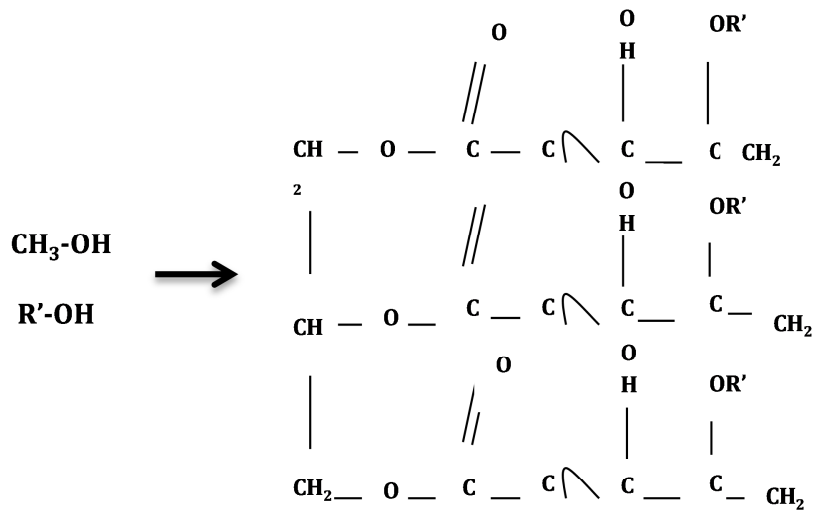

Metanol

Gambar 2. Hidroksilasi epoksi jarak pagar menggunakan metanol alkil R' pada poliol jarak pagar berasal dari metanol ( $\left.\mathrm{R}^{\prime}-\mathrm{OH}\right)$ 


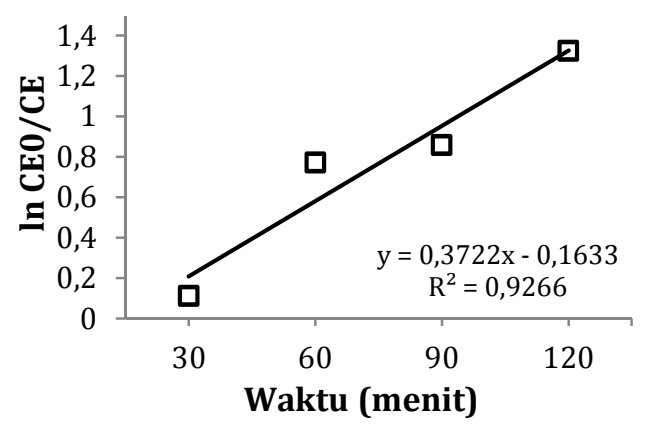

Gambar 3. Hubungan waktu (t) dan In $\left(\mathrm{C}_{\mathrm{E} 0} / \mathrm{C}_{\mathrm{E}}\right)$ pada $50^{\circ} \mathrm{C}$

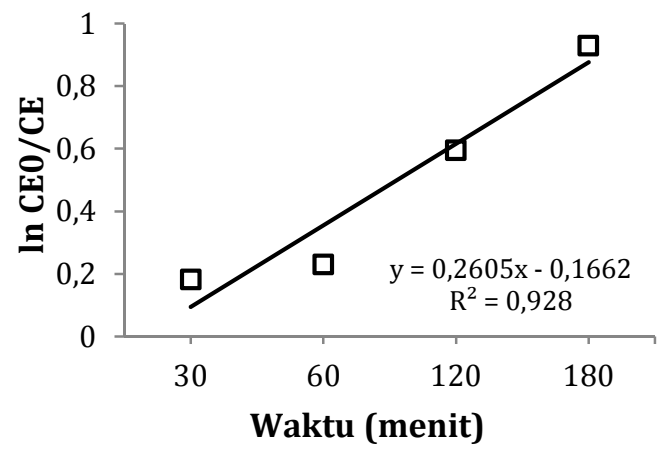

Gambar 4. Hubungan waktu (t) dan In $\left(\mathrm{C}_{\mathrm{E} 0} / \mathrm{C}_{\mathrm{E}}\right)$ pada $60^{\circ} \mathrm{C}$

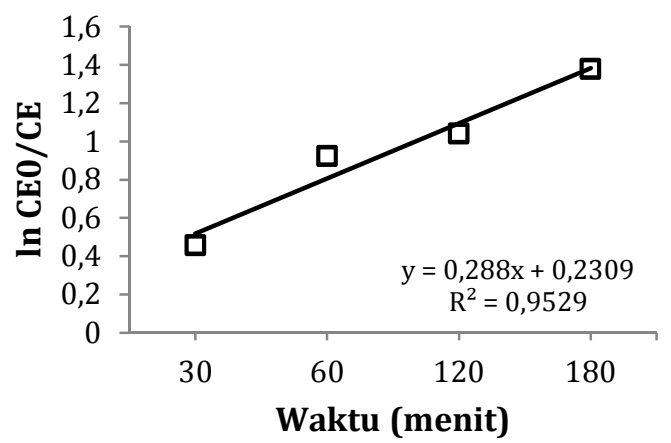

Gambar 5. Hubungan waktu (t) dan In $\left(\mathrm{C}_{\mathrm{E} 0} / \mathrm{C}_{\mathrm{E}}\right)$ pada $65^{\circ} \mathrm{C}$

Tabel 1. Konstanta Laju Reaksi Hidroksilasi Epoksi Minyak Jarak Pagar dengan Metanol dan Katalis Bentonit

\begin{tabular}{cc}
\hline $\begin{array}{c}\text { Suhu } \\
{ }^{\mathbf{C}} \mathbf{C}\end{array}$ & $\begin{array}{c}\mathbf{k}^{\prime}, \text { konstanta laju reaksi } \\
\text { semu (1/menit) }\end{array}$ \\
\hline 50 & 0,3722 \\
60 & 0,2605 \\
65 & 0,2880 \\
\hline
\end{tabular}

Semakin tinggi suhu, maka akan semakin mendekati titik didih metanol $(64,7$ $\left.{ }^{\circ} \mathrm{C}\right)$, akibatnya mendekati kondisi jenuhnya, sehingga pada suhu $50{ }^{\circ} \mathrm{C}$ nilai $\mathrm{k}$ lebih besar, karena reaksi hidroksilasi lebih cepat terjadi. Dengan menggunakan pendekatan reaksi elementer dan pseudo-homogen maka nilai $\mathrm{k}^{\prime}$ adalah seperti persamaan 4 .

$k^{\prime}=k\left[\mathrm{CH}_{3} \mathrm{OH}\right]=k C_{M}=k(\mathrm{Me})$

Maka persamaan laju reaksi pembukaan ikatan pada gugus oksirana epoksi minyak jarak pagar menggunakan metanol dan katalis bentonit dengan pendekatan pseudo-homogen adalah k.Ep.Me atau k'.Ep. Sebagai perbandingan adalah laju reaksi pembukaan ikatan pada gugus oksirana epoksi minyak kedelai menggunakan metanol tanpa katalis yang dilakukan oleh Lin dkk. 2008, adalah k.Ep.(Me) ${ }^{2}$.

\section{Termodinamika pada Reaksi Hidroksilasi terhadap Epoksi Jarak Pagar}

Besarnya Energi Aktivasi (Ea) dapat ditentukan dengan menggunakan persamaan Arrhenius, yaitu:

$k=A e^{-\frac{E a}{R T}}$

Besarnya energi aktivasi reaksi hidroksilasi terhadap epoksi jarak pagar menggunakan methanol dengan katalis bentonit adalah 7,63 kkal mol-1. Entalpi $(\Delta \mathrm{H})$ dapat dihitung dengan menggunakan persamaan Teori Keadaan Transisi (Levenspiel, 2006) seperti pada Persamaan 6. Besar $\Delta \mathrm{H}$ adalah 8,27 kkal mol${ }^{-1}$.

$E a=\Delta H-R T$

\section{KESIMPULAN}

Modifikasi kimiawi, yaitu epoksidasi dan hidroksilasi dapat meningkatkan performa minyak jarak pagar. Sesuai tujuan penelitian yaitu membandingkan karakterisasi produk poliol yang terbentuk menggunakan beberapa pereaksi dan katalis pada reaksi hidroksilasi terhadap epoksi jarak pagar, bahwa pada kondisi operasi yang berbeda didapatkan poliol yang berasal dari pereaksi metanol dan katalis bentonit menghasilkan bilangan hidroksil terbesar yaitu 165,77 . Hidroksilasi pada epoksi jarak pagar menggunakan metanol dan katalis padat bentonit, diidentifikasi dengan turunnya bilangan oksirana dan turunnya puncak absorpsi gugus epoksi pada panjang gelombang 824-842 $\mathrm{cm}^{-1}$ dan meningkatnya gugus hidroksil pada puncak absorpsi dari 
panjang gelombang $\quad 3450-3800 \mathrm{~cm}^{-1}$. Bilangan oksirana epoksi jarak pagar adalah sebesar 4,7\% dan hasil reaksi hidroksilasi yaitu pembukaan gugus oksirana adalah sebesar 0,05\%. Studi kinetika menghasilkan persamaan kecepatan reaksi pembukaan gugus oksirana membentuk gugus hidroksil yaitu $-\mathrm{d}(\mathrm{Ep}) / \mathrm{dt}=\mathrm{k}^{\prime} . \mathrm{Ep}=\mathrm{k}$,Ep.Me dengan nilai $\mathrm{k}^{\prime}$ adalah konstanta laju reaksi pseudo, yaitu $\mathrm{k} \mathrm{x}$ Me. Besarnya parameter termodinamika, yaitu entalpi $(\Delta H)$ dan energi aktivasi $\left(E_{\mathrm{a}}\right)$ masing-masing sebesar $8,27 \mathrm{kcal} \mathrm{mol}^{-1}$ dan $7,63 \mathrm{kcal} \mathrm{mol}^{-1}$.

\section{DAFTAR NOTASI}

$\mathrm{A}=$ faktor frekuensi tumbukan

$\mathrm{C}_{\mathrm{E}}=(\mathrm{Ep})=$ konsentrasi epoksi jarak pagar

$\mathrm{C}_{\mathrm{M}}=(\mathrm{Me})=$ konsentrasi metanol

$\mathrm{C}_{\mathrm{P}}=$ konsentrasi poliol

$\mathrm{Ea} \quad=$ energi aktivasi

$\mathrm{E} \quad=$ reaktan epoksi minyak jarak pagar

$\mathrm{M}=$ reaktan metanol

$\Delta \mathrm{H}=$ entalpi

$\mathrm{k}=$ konstanta kecepatan reaksi hidroksilasi

$\mathrm{k}^{\prime} \quad=$ konstanta kecepatan reaksi hidroksilasi semu

$\mathrm{P} \quad=\operatorname{produk}$ reaksi (poliol)

$\mathrm{R}=$ konstanta gas ideal $=1,987 \mathrm{kal} \mathrm{K}^{-1}$ $\mathrm{mol}^{-1}$

$\mathrm{R}^{\prime} \quad=$ alkil

$\mathrm{R}^{2}=$ determinasi, besarnya pengaruh variabel independen terhadap variabel dependen secara simultan atau bersama-sama

$-\mathrm{r}_{\mathrm{E}} \quad=$ kecepatan berkurangnya konsentrasi oksirana

$\mathrm{T}=$ temperatur $(\mathrm{K})$

\section{DAFTAR PUSTAKA}

Bargaya, F. A.; Criz, M. I.; Gatineau, L.; Fripiat, J. J., Adsorption of alcohol by smectites: IV. Models, Clay Minerals, 1981, 16(1), 115-122.

Campanella, A.; Baltanás, M. A., Degradation of oxirane ring of epoxidized vegetable oils in liquid-liquid heterogeneous reaction systems, Chemical Engineering Journal, 2006, 118(3), 141-152.

Chauhan, B. S., Principles of Biochemistry and Biophysics; University Science Press: New Delhi, 2008; hlm. 146.
El-Diwani, G.; El Rafei, S.; Hawash, S.; Khalil, A. A., Recovery of phorbol from oil of an egyptian jatropha, Asian Journal of Plant Sciences, 2012, 11(3), 117-123.

Hwang, H. S.; Erhan, S. Z., Synthetic lubricant basestocks from epoxidized soybean oil and Guerbet alcohols, Industrial Crops and Products, 2006, 23(3), 311-317.

Hodar, F. J. M., Heterogeneous Catalysis, Lecture, Advanced Catalysis and Organometallic Chemistry Intensive Programs (IP) Lifelong Learning Program Erasmus, Camerino, Italy, 2009.

Kaurav, M. S., Engineering Chemistry with Laboratory Experiments; PHI Learning Private Limited: New Delhi, 2011; hlm. 209.

Kiatsimkul, P.; Suppes, G. J.; Hsieh, F.; Lozada, Z.; Tu Y. C., Preparation of high hydroxyl equivalent weight polyols from vegetable oils, Industrial Crops and Products, 2008, 27(3), 257-264.

Levenspiel, O., Chemical Reaction Engineering; John Wiley \& Sons: New York, 2006.

Lathi, P. S.; Mattiasson, B., Green approach for the preparation of biodegradable lubricant base stock from epoxidized vegetable oil, Applied Catalysis B: Environmental, 2006, 69 (3-4), 207-212.

Lin, B.; Yang, L.; Dai, H.; Yi, A., Kinetic studies on oxirane cleavage of epoxidized soybean oil by methanol and characterization of polyols, Journal of the American Oil Chemists' Society, 2008, 85(2), 113-117.

Liu, Y. H.; Liu, Q. S.; Zhang, Z. H., Amberlyst-15 as a new and reuseable catalyst for regioselective ring-opening reactions of epoxides to $\beta$-alkoxy alcohols, Journal of Molecular Catalysis A: Chemical, 2008, 296 (1), 42-46.

Olebunne, F. L.; Igbokwe, P. K.; Onyelucheya 0. E.; Osoka, E. C.; Ekeke, I. C., Mechanistic modeling of clay-catalysed liquid-phase esterification of acetic acid, Journal of Emerging Trends in Engineering and Applied Sciences, 2011, 2(4), 631-635. 
Megawati; Sediawan, W. B.; Sulistyo, H.; Hidayat, M., Pseudo-homogeneous kinetic of dilute-acid hydrolysis of rice husk for ethanol production: effect of sugar degradation, International Journal of Engineering and Applied Sciences, 2010, 6(1), 135-140.

Nugrahani, R. A., Perancangan Proses Pembuatan Pelumas Dasar Sintetis dari Minyak Jarak Pagar (Jatropha Curcas L.): Hasil Modifikasi, Disertasi Doktor, Institut Pertanian Bogor, 2008.

Nugrahani, R. A.; Firdaus, F. E.; Widyawati, Y.; Firginia, H.; Purnama, R., Kondisi Optimum Reaksi Hidroksilasi terhadap Epoksi Jarak Pagar (Jatropha curcas L.) Menggunakan Asam Asetat Glasial dengan Katalis Resin, Prosiding Seminar Nasional Teknik Kimia Indonesia dan Musyawarah Nasional APTEKINDO, Jakarta, 20-21 September 2012, 839-846.

Nugrahani, R. A.; Mangunwidjaja, D.; Suryani, A.; Machfud; Sudradjat, R., Optimasi proses dan kinetika reaksi epoksidasi minyak jarak pagar (Jatropha curcas L.) dengan hidrogen peroksida, Jurnal Teknologi Industri Pertanian, 2007, 18(2), 66-70.

Nzikou, J. M.; Matos, L.; Mbemba, F.; Ndangui, C. B.; Pambou-Tobi, N. P. G.; Kimbonguila, A.; Silou, Th.; Linder, M.; Desobry, S., Characteristics and composition of Jatropha curcas oils, variety congo-brazzaville, Research Journal of Applied Sciences,
Engineering and Technology, 2009, 1(3), 154159.

Okieimen, F. E.; Bakare, O. I.; Okieimen, C. O., Studies on the epoxidation of rubber seed oil, Industrial Crops and Products, 2002, 15(2), 139-144.

Petrovic, Z.; Guo, A.; Javni, I., Process for the Preparation of Vegetable Oil-Based Polyols and Electroinsulating Casting Compounds Created from Vegetable Oil-Based Polyols, U.S. Patent 6,573,354, 3 Juni 2003.

Purwanto, E., The Synthesis of Polyol from Rice Bran Oil (RBO) through Epoxidation and Hydroxylation Reactions, Tesis Magister, University of Adelaide, 2010.

Rustamaji, H.; Sulistyo, H.; Budiman, A.; Pemodelan dan simulasi kinetika reaksi alkoholisis minyak jarak pagar Uatropha curcas) dengan katalisator zirkonia tersulfatasi, Jurnal Rekayasa Proses, 2010, $4(1), 19-24$.

Zeng, Z., Cui, L.; Xue, W.; Chen, J.; Che, Y; Recent Developments on the Mechanism and Kinetics of Esterification Reaction Promoted by Various Catalysts; dalam Chemical Kinetics, Ed. Vitek Patel, 2012, http://www.intechopen. com/books/chemical-kinetics/recent-develop ments-on-the-mechanism-and-kinetics-of-est erification-reaction-promoted-by-various-cat (akses 2012). 